Review Articles

\title{
Correlation of Biodiversity of Algal Genera with Special Reference to the Waste Water Effluents from Industries
}

\author{
${ }^{1}$ Ritu Singh Rajput, ${ }^{2}$ Sonali Pandey and ${ }^{3}$ Seema Bhadauria \\ ${ }^{1}$ Department of Microbiology, JECRC University, Jaipur, India \\ ${ }^{2}$ Department of Botany, JECRC University, Jaipur, India \\ ${ }^{3}$ Department of Microbiology, JECRC University, Jaipur, India
}

Article history

Received: 05-11-2016

Revised: 29-11-2016

Accepted: 08-12-2016

Corresponding Author:

Sonali Pandey

Department of Botany, JECRC

University, Jaipur, India

Email: drsonali17@gmail.com

\begin{abstract}
Pollution is the introduction of contaminants, which cause adverse change, into the natural environment and mainly from external inputs like sewage, waste from industries, oil spills and agricultural use of pesticides. Anthropogenic activity-reflected in the use of toxic metals and organic pollutants-has increased levels of soil contamination and damage to aquatic systems. Ecosystems maintain water quality and withstand pressure from pollution better if they are naturally equipped with biodiversity. Algae regularly develop in fresh water and seawater and some species grow in high-salt environments. Algae quickly reponds to changes in their environment as a consequence of changes in water chemistry, affecting their diversity, community composition and abundance. Recently, algae have been used in bioremediation and to cleanup wastewater due to their high efficiency in absorbing both organic and inorganic pollutants, incuding dissolved nutrients, heavy metals, pesticides, toxic compounds and even radiactive materials. Almost all freshwater ecosystems depend on phytoplankton because they are producers and participate in the aquatic food chain; they are also useful for water quality assessment. The present work is an effort to determine the range of variation among different groups of algae. Our results showed that four species dominated the microbial community in eutrophic waters, namely Euglena (Euglenophyta), Nitzschia (Bacillariophyta), Oscillatoria and Phormidium (Cyanophyta).
\end{abstract}

Keywords: Water Pollution, Algae, Environment, Wastewater, Heavy Metal, Ecosystem

\section{Introduction}

Pollution exists when harmful substances are introduced into the natural environment. Pollution can come from manufactured substances or human-generated noise, heat or light. Water is a critical asset that every life form needs to survive (Howells, 1994). Contaminated water contains harmful substances that affect plants and animals. The primary contributors to water contamination are sewage, industrial waste, oil spills and the use of pesticides in agriculture. When untreated sewage is released into streams, it causes sicknesses such as typhoid, dysentery and cholera. Industrial waste water is a primary wellspring of water contamination. In the 21 st century, tremendous amounts of mechanical waste water were discharged into rivers, lakes and ponds. Both organic pollutants and heavy metals are considered serious threats to human health and their occurrence have been reported to increase in the recent years associated with anthropogenic inputs (Chekroun and Baghour, 2013). Algae may present a solution to some of these contamination problems. Algae consistently develop in fresh water and seawater and a few species develop in high-salt environments. The sensitivity of some algal species in the changes in their environment (i.e., nutrients) as manifested in the changes in their community structure and abundance, making them good indicators of the health of the ecosystem. Further, they could efficiently absorb both organic and inorganic pollutants like excess fertilizers, heavy metals, pesticides, toxic compounds and radioactive materials and store them in their cells (Jothinayagi and Anbazhagan, 2009). These make allow the algae to be used for water purification or "bioremediation". The latter has been introduced to describe the procedure of using biological agents to expel toxic waste from the environment. Bioremediation is the best natural instrument to deal with the polluted environment. 


\section{Literature Review}

The value of algae as a bioindicator for water has been recognized since the mid-nineteenth century. Algae are most helpful as bioindicators in the context of eutrophication; however, they are additionally used to identify organic pollution due to their well-documented tolerance (Palmer, 1969). Algal community composition and the abundance of some sensitive species have been used to assess the ecological condition of an aquatic ecosystem and thus, are useful indicators in assessing water quality of diverse habitats (Diwedi, 2010). Sensitive species or bioindicators specifically are useful in determining and qualifying the effects of pollutants in the environment. In addition, bioindicators could also indicate the process of accumulation and turnover rate of different pollutants in the ecosystem, allowing us to predict the how long pollution may persist. Although some indicator may be any species that could be linked to a certain environmental variable, algae in general are reliable indicators of pollution for many reasons. Their distribution greatly varied in both time and space, with apparent succession depending on season all throughout the year. Algae respond quickly to the pollution of the surroundings, manifested in the accumulation of high biomass that are easy to detect and sample. Presence of some algal species strongly correlated with the presence of specific types of pollutants, especially organic ones (Sen et al., 2013).

\section{Algal Species Present in Wastewater}

A total of five algal species were identified to be potential indicators of degree of pollution in England aquatic bodies. Stigeoclonium tenueis was observed to be associated with the downstream section of the heavily polluted part of a river. The diatoms Nitzschia palea and Gomphonema parvulum seemed to dominated the perennially eutrophic waters, while Cocconeis and Chamaesiphon both occurred in the polluted and remediated or treated zones of the river. Kolwitz (year) reported 61 diatoms, 42 algae, 41 pigmented flagellates, 2 blue-green algae and 5 red algae to be abundant in as oligosaprobic and/or pristine environments. Some algae, protists and the diatoms Navicula, Synedra and bluegreen algae Oscillatoria and Phormidium were reported to tolerate well high concentrations of organic pollutants (Palmer, 1969). Some were also reported to remove heavy metals, although their capacity varied with species. For example, some studies showed that Oscillatoria could successfully remove chromium, while Chlorella vulgaris is effective in remediating cadmium, copper and zinc. The green alga Chlamydomonas is good for the removal of lead; and Scenedesmus chlorelloides for molybdenum (Filip et al., 1979). Lackey (year) also found 77 species of phytoplankton inhabiting the pristine waters of a portion of a small river.

\section{Organic Matter in Industrial Waste Material}

Organic and inorganic substances that are released into the atmosphere as the result of domestic, agricultural and industrial water activities result in organic and inorganic pollution (Mouchet, 1986; Lim et al., 2010).

The characterization of Algal Organic Matter (AOM) is derived from the green algae Chlamydomonas geitleri, the phytoplankton Fragilaria crotonensis and the cyanobacteria Microcystis aeruginosa. The growth of the phytoplankton was monitored by cell counting optical density measurements and dissolved organic carbon concentration. Cellular Organic Matter (COM) and Extracellular Organic Matter (EOM) were characterized by looking at their protein content, hydrophobicity and molecular weights. It was discovered that each EOM and $\mathrm{COM}$ was preponderantly hydrophilic. COM contained higher super molecule content than EOM. The character and molecular weight distribution of EOM/COM were dependent on the species and growth phase of phytoplankton (Baresova et al., 2009).

\section{Inorganic Matter: $(N, P, S)$ in Industrial Wastewater}

Industrial wastes often contain high concentrations of inorganic compounds like sodium, calcium, potassium, magnesium, chlorine, sulphur, phosphate, carbonate, ammonia salts and some heavy metals (Tebbutt, 1997). De la Noüe et al. (1992) reported that the total nitrogen and phosphorus contents of industrial and agricultural effluents were three orders of magnitude higher than natural waters. Short-run summer effects of these compounds on algal colonization, abundance and species composition in moderate herbivore treatments were investigated in moderate herbivore treatments. A later succession of algae on coral skeletons was investigated under four treatments conditions, namelyan untreated (control), one with added phosphate, supplanted with and one were the 2 were mixed. Responses were measured using turf algal cover as the measure of algal abundance Results showed that treatments with added nitrogen produced three times higher turf cover when compared with the pure phosphorus treatment. The turf communities were mostly dominated by green and blue-green algae, particularly Enteromorpha prolifera and Lyngbya confervoides and two species of Cladophora. Encrusting corallines dominated the phosphate treatment and therefore the blue-green algae Lyngbya confervoides, whereas the highest cover of frondose brown algae was found in the controls, namely Padina sanctae-crucis and two species of Dictyota. Results indicated that turf algae were co-limited by chemical element and phosphorus; however, enrichment seemed to inhibit the brown frondose algae that presently dominate these reefs. Interestingly, communities grown either in $\mathrm{P}$ or $\mathrm{N}$-only treatments showed the lowest number of species and 
highest in the controls and those with both fertilizers suggesting that the N:P ratio is important in sustaining growth and diversity (McClanahan et al., 2007).

Follow-up studies were conducted to evaluate the potential of algae to grow in conditions with high dissolved organic nitrogen compounds, while testing for its different sources. To do this, cultures of many common lake algae like Pediastrum duplex, Synechococcus sp., Microsystis aeruginosa were incubated for three weeks in the laboratory with completely different inorganic/organic nutrient sources and their growth were monitored for the duration of the study (Berman and Chava, 1999). Using labelled ${ }^{15} \mathrm{~N}$ and

${ }^{33} \mathrm{P}$ tracers, the turnover of organic and inorganic $\mathrm{N}$ and $\mathrm{P}$ and their partitioning into two size fractions of marine osmotrophs were determined in a mesocosm study. The larger size fraction $(>0.8 \mu \mathrm{m})$, mainly made up of the coccolithophorid Emiliania huxleyi, dominated the uptake of as the bloom progressed and increased in quantity of huge particle-associated microorganism. $\mathrm{N}$ (from leucine) and P (from ATP and dissolved DNA) uptakes were first carried out by organisms in the 0.8-0.2 $\mu \mathrm{m}$ size fraction but this shifted towards the $>0.8 \mu \mathrm{m}$ size fraction as the system shifted to become N-deficient. Normalizing uptake to phytoplankton and heterotrophic biomasses revealed that a higher specific affinity for leucine- $\mathrm{N}$ was shown for organisms within the 0.8-0.2 $\mu \mathrm{m}$ size fraction than those within the larger fraction once $\mathrm{N}$ became deficient, whereas the opposite was observed for $\mathrm{NH}_{4}$. There was no significant difference in specific preference for phosphorus substrates. Since heterotrophic groups appear to amass nitrogen from organic compounds more efficiently than phytoplankton like leucine, this indicates a completely different structuring of the microbial food chain in N-limited relative to P-limited environments (Løvdal et al., 2007).

\section{Industrial Rich Cellulose}

Nagaon Paper Mill (NPM), placed into service in 1985 in Jagi Road, Assam (India) has been emitting solid, liquid and gaseous wastes affecting the environmental conditions of the surrounding areas. The main problem has been associated with the disposal of effluents into nearby land areas or land systems (Goswami, 1998).

The NPM discharges heavily loaded waste effluents into Elenga Beel, Moriga, at a rate of $2100 \mathrm{~m}^{3} / \mathrm{h}$ The higher diversity of chemicals in the Paper Mill Effluents (PME) degrades water quality endangering aquatic life. The effluent also alters the physico-chemical and biological profiles of the receiving water body. Among the present aquatic organisms, algae are extremely sensitive to pollutants making them primary indicators of these changes. Any disturbances in their environment might would also result to changes in the algal communities in terms abundance, diversity and community structure (Saikia and Lohar, 2012).
Food and fuel production are two issues that are interdependent and interconnected. Ideally, a carbonsmart society should be able to provide all the demands for both food and fuel sustainably. The increasing popularity and use of "biorefineries" in different industries are suggested to fill in the demands for supplies but at the same time, curb problems and issues related to several environmental issues like greenhouse gas emissions, fuel usage, land use modification for fuel production and future food insufficiency. A new concept of biorefinery-based integrated industrial ecology encompasses the various measures of the production chain, co-production and services from bio-refinery industries (Subhadra, 2011).

Macroalgae are remarkable sources of a myriad of various bioactive polysaccharides that have both industrial and novel food applications. However, upscale productions would need to utilize cultivated seaweeds as carbohydrate resource for various fuel production. The ability of the plant to exploit nature's free energy (photosynthesis) and the resulting biomass makes it a renewable and possible sustainable material source for various applications. Macro algae are economical solar-power converters and might produce massive amounts of biomass in a very short time; however, biomass from the marine environment is a commonly associated unremarked resource and possibly represents a big reseervoir of carbohydrates as a source of renewable energy (Kraan, 2012).

\section{Heavy Metals in Wastewater}

Heavy metal contaminations could pose serious environmental hazards due to their abundance and widespread persistence. Analysis of heavy metals in some industrial effluents (e.g., arsenic, cadmium, chromium, copper, iron, manganese, nickel, lead and zinc), revealed that. $\mathrm{As}, \mathrm{Cd}, \mathrm{Cr}$ and $\mathrm{Pb}$ were not found in any studied wastewater samples, whereas a number of the remaining heavy metals $(\mathrm{Cu}, \mathrm{Fe}, \mathrm{Mn}, \mathrm{Ni}$ and $\mathrm{Zn})$ were found higher than the permissible quality limit (Singh and Chandel, 2006). Several studies highlighted bioremediation capacity of some micro- and macro-algal species to absorb organic and inorganic pollutants. Some of these species have high growth rates, which is an advantage for phytoremediation. However, some variable could also limit its efficiency especially when tested in contaminated sites (Chekroun and Baghour, 2013).

Studies of heavy metals in Vartur Lake, Bangalore, revealed that $\mathrm{Cd}, \mathrm{Co}, \mathrm{Cr}, \mathrm{Ni}$ and $\mathrm{Pb}$ all exceeded drinking water standards. $\mathrm{Cr}$ exceeded the CPCB's permissible limits for waters affected by effluents. In Eichornia crassipes, Cd, $\mathrm{Co}, \mathrm{Cr}$ and $\mathrm{Ni}$ were important and within the sediments, $\mathrm{Cd}$ and $\mathrm{Ni}$ exceeded the Permissible Exposure Limit (PEL). The Geo-accumulation Index as observed in the sediments of the lake, only showed moderate contamination of Mn, $\mathrm{Cu}$ and $\mathrm{Pb}$. Although $\mathrm{Cr}$ had the highest concentration among the heavy metals detected, its bioavailability in 
plants $(71.5 \mathrm{ppm})$ was lower than that available to manganese (192.3 ppm). This high level of metals in sediment demands that immediate action to be initiated to implement necessary environmental mitigation measures for the lake (Jumbe and Nandini, 2009).

Algae are proven economical biological vectors for heavy metal uptake; the underlying processes for their biosorption activity have been extensively studied using microorganism as the model system to investigate heavy metal ions removal. The ability of various species of yeasts, fungi, bacteria and algae to remove metal ions was investigated. Using aquatic systems as a sink for the discharge of heavy metals has become a concern in recent years. Batch experiments have been conducted to attempt removal of single metal ions from a suite of 6 bioabsorbable elements from artificial wastewaters. An algal strain cultivated at the National Chemical Laboratory (NCL) and another one from a natural environment were tested for their capacity to remove $\mathrm{Cr}, \mathrm{Cu}, \mathrm{Fe}, \mathrm{Mn}$, selenium $(\mathrm{Se})$ and $\mathrm{Zn}$ from a solution. The algae were incubated with the said heavy metals and their residual concentrations were determined after incubation using an ultraviolet radiation spectrophotometer. Results showed that the highest percentage removal was observed in cultures of Spirogyra sp., specially for $\mathrm{Cr}(98.23 \%), \mathrm{Cu}(89.6 \%), \mathrm{Fe}$ (99.73\%), Mn (99.6\%), Se (98.16\%) and Zn (81.53\%). Similarly, Spirulina sp removal for $\mathrm{Cr}$ (98.3\%), $\mathrm{Cu}$
$(81.2 \%), \mathrm{Fe}(98.93 \%), \mathrm{Mn}(99.73 \%)$, Se $(98.83 \%)$ and $\mathrm{Zn}$ (79\%) were also high compared to the starting concentration of $5 \mathrm{mg} \mathrm{L}^{-1}$ (Mane and Bhosle, 2012).

\section{Analysis of Sewage Wastewater}

Pollutants may come from different sources, such as discharges of either raw or treated sewage from urbanized areas, industrial plants, as run-off from agricultural lands and leachates from solid waste disposal sites (Horan, 1989). Navicula accomoda is cited as a to be a good indicator of sewage/organic pollution since it has been observed to occur more abundantly in heavily polluted areas where many other species cannot thrive (Archibald, 1972).

Physico-chemical analysis of waste water (water that was drawn from underground sources, utilized in dye industries and turned into waste water) was collected from Sanganer Town and had been significantly influenced by nearby agricultural fields. Results showed that that the $\mathrm{pH}$ of the waste water ranged from 7.35 to 9.38 , electrical conductivity between 0.87 to $1.15 \mathrm{umho} / \mathrm{cm}$ and total solids of 955.8 to $2010.2 \mathrm{mg} \mathrm{L}^{-1}$. Analysis of other heavy metals revealed high presence of $\mathrm{Pb} 1.098, \mathrm{mg} \mathrm{L}^{-1}, \mathrm{Fe}$ $0.161 \mathrm{mg} \mathrm{L}^{-1}, \mathrm{Cu} 4.66 \mathrm{mg} \mathrm{L}^{-1}, \mathrm{Cd} 1.98 \mathrm{mg} \mathrm{L}^{-1}, \mathrm{Zn}$ $3.29 \mathrm{mg} \mathrm{L}^{-1}$, Ni $0.076 \mathrm{mg} \mathrm{L}^{-1}$ and $\mathrm{Cr} 3.96 \mathrm{mg} \mathrm{L}^{-1}$ (Jaishree and Khan, 2014).

Table 1 . Heavy metal absorbing algae

\begin{tabular}{|c|c|c|c|}
\hline Algae & Genera & Heavy metals & References \\
\hline $\begin{array}{l}\text { Phormidium sp. } \\
P . \text { bohner } \\
P . \text { ambigunum } \\
\text { P. corium }\end{array}$ & Cyanophyceae & $\begin{array}{l}\mathrm{Cd}, \mathrm{Zn}, \mathrm{Pb}, \mathrm{Ni}, \mathrm{Cu} \\
\mathrm{Cr}, \mathrm{Hg},\end{array}$ & $\begin{array}{l}\text { Wang et al. (1995; Dwivedi, 2012; } \\
\text { Shanab et al., 2012) }\end{array}$ \\
\hline $\begin{array}{l}\text { Oscillatoria quadripunctulata } \\
\text { Oscillatori atenius }\end{array}$ & Cyanophyceae & $\mathrm{Cd}, \mathrm{Ni}, \mathrm{Zn}$ & Ajayan et al. (2011; Azizi et al., 2012) \\
\hline $\begin{array}{l}\text { Scenedesmus acutus } \\
\text { Scenedesmus quadricauda }\end{array}$ & Chlorophyceae & $\mathrm{Cr}, \mathrm{Hg}, \mathrm{Cd}, \mathrm{Pb}$ & $\begin{array}{l}\text { Travieso et al. (1999; Cañizares-Villanueva et al., } \\
\text { 2001; Shanab et al., 2012) }\end{array}$ \\
\hline $\begin{array}{l}\text { Euglena gracilis } \\
\text { Spirogyra hyaline }\end{array}$ & Euglenophyceae & $\mathrm{Zn}$ & Fukami et al. (1988) \\
\hline $\begin{array}{l}\text { Spirogyra halliensis } \\
\text { Spirogyra sp. }\end{array}$ & Chlorophyceae & $\begin{array}{l}\mathrm{Cd}, \mathrm{Hg}, \mathrm{As}, \mathrm{Pb}, \mathrm{Co}, \mathrm{Ni} \\
\mathrm{Cr}, \mathrm{Fe}, \mathrm{Mn}, \mathrm{Cu}, \mathrm{Zn}\end{array}$ & $\begin{array}{l}\text { Kumar and Oommen (2012; Mane and Bhosle, } \\
\text { 2012) }\end{array}$ \\
\hline $\begin{array}{l}\text { Chlorella vulgaris, Chlorella } \\
\text { Sorokiniana, Chlorella sp }\end{array}$ & Chlorophyceae & $\mathrm{Cd}, \mathrm{Cr}, \mathrm{Zn}$ & $\begin{array}{l}\text { Matsunaga et al. (1999; Travieso et al., } 1999 \\
\text { Yoshida et al., 2006; Rehman, 2003) }\end{array}$ \\
\hline Spirullina.sp. & Cyanophyceae & $\mathrm{Cr}, \mathrm{Cu}, \mathrm{Zn}, \mathrm{Mn}, \mathrm{Fe}$ & Mane and Bhosle (2012) \\
\hline Cladophora glomeraa & Ulvophyceae & $\mathrm{Zn}, \mathrm{Cu}$ & Vymazal (1990) \\
\hline Oedogonium rivulare & Chlorophyceae & $\mathrm{Pd}, \mathrm{Cd}, \mathrm{Co}$ & Atici et al. (2010) \\
\hline Ascophyllum nodosm & Phaeophyceae & $\mathrm{Au}, \mathrm{Co}, \mathrm{Ni}, \mathrm{Pb}$ & $\begin{array}{l}\text { Kuyucak and Volesky (1989; 1988; } \\
\text { Holan and Volesky, 1994) }\end{array}$ \\
\hline Caulerpa racemosa & Chlorophyceae & $\mathrm{B}$ & Bursali et al. (2009) \\
\hline Fucus vesiculosus & Phaeophyceae & $\mathrm{Zn}, \mathrm{Ni}$ & Fourest and Volesky (1997; Holan and Volesky, 1994) \\
\hline Laminaria japonica & Phaeophyceae & $\mathrm{Zn}$ & Fourest and Volesky (1997) \\
\hline Micrasterias denticulate & Zygnemophyceae & $\mathrm{Cd}$ & Volland et al. (2013) \\
\hline Phormedium bohner & Cyanophyceae & $\mathrm{Cr}$ & Dwivedi (2012) \\
\hline $\begin{array}{l}\text { Sargassum filipendula Sargassum } \\
\text { fluitans Sargassum natans } \\
\text { Sargassum vulgare }\end{array}$ & Phaeophyceae & $\mathrm{Cu}, \mathrm{Fe}, \mathrm{Zn}, \mathrm{Ni}, \mathrm{Pb}$ & $\begin{array}{l}\text { Davis et al. (2000; Figueira et al., 1997; Fourest and } \\
\text { Volesky, 1997; Holan and Volesky, 1994) }\end{array}$ \\
\hline Tetraselmis chuil & Chlorophyceae & As & Irgolic et al. (1977) \\
\hline Navicula sp. & Bacillariophyceae & $\mathrm{Cd}, \mathrm{Pb}, \mathrm{Hg}, \mathrm{Cr}$ & Atici et al. (2010) \\
\hline
\end{tabular}


Evaluating some physical and chemical soil properties in Amanisha-nala of Jaipur City throughout the monsoon season (June-September) and assessing the quality of soil are crucial for determining its suitability for agricultural and irrigation purposes. Physicochemical parameters of soil like $\mathrm{pH}, \mathrm{EC}$, available organic-carbon, phosphate, potassium hydroxide and micronutrients like $\mathrm{Zn}, \mathrm{Fe}, \mathrm{Cu}$ and $\mathrm{Mn}$ were also analyzed (Rawatani and Singh, 2011).

The textile business consumes great quantities of clean water and turn also produces massive volumes of wastewater from printing and dyeing units with color that contains residues of reactive dyes and chemicals, which are needed to be treated before being discharged into the environment. Discharged colored organic compounds in effluent contaminate the water and are a source of non-aesthetic pollution and eutrophication (Pokharna and Shrivastava, 2013).

The dye decolorizing bacteria, were identified in sludge collected from Amanisha-nala, Sanganer, Jaipur. Bacterial isolates were used to optimize completely different parameters for decolorizing light red dye, such as varied temperature, $\mathrm{pH}$, the sources of carbon and nitrogen (Sethi et al., 2012).

Phytoremediation is defined as a procedure of purifying soil and aquatic systems by utilizing plants, algae to assimilate heavy metals. The algae have numerous elements that build them excellent candidate for the actual expulsion and concentration of heavy metals (Table 1), that incorporate high tolerance to heavy metals, capability to grow every autotrophically and heterotrophically, huge surface territory/volume proportions (Mitra et al., 2012).

\section{Conclusion}

Water is a universal necessity of all living organisms and one of the most abundant compounds in the world. Every living being in our planet needs water for survival and growth. However, increased human population, industrialization, utilization of agricultural fertilizers and other anthropogenic activities have significantly contributed to the pollution of aquatic systems with different harmful contaminants. Industrial effluents, untreated water and soil contamination are the predictable products of industrial development. Most of the rivers in the urban areas of developing countries are the endpoints for effluents released from the industries.

African and Asian countries are experiencing rapid industrial growths and expansion, making environmental conservation a difficult task to accomplish. Most effluents from domestic, agricultural and industrial use and their discharge into the environment results to organic and inorganic pollution. Algae respond quickly and predictably to a large range of pollutants, which could be used as early warning or monitoring tools in assessing signals of deteriorating conditions and their potential causes. Due to their nutritional preferences and as the base of the food chain, algal indicators provide more distinctive information regarding ecosystem conditions compared to some known animal indicators. These ecologically relevant signals, which denote ecosystem changes, could then be used to differentiate and distinguish acceptable from unacceptable environmental conditions. Algal indicators are more cost-effective observation tool. The $\mathrm{N}: \mathrm{P}$ ratio often determines which algal groups or species would dominate the community.

\section{Author's Contributions}

Ritu Singh Rajput: Data collection, Data analysis and interpretation.

Sonali Pandey: Conception or design of the work Final approval of the version to be published.

Seema Bhadauria: Critical revision of the article.

\section{Ethics}

This article is original. The corresponding author confirms that all of the other authors have read and approved the manuscript and no ethical issues involved. Authors should address any ethical issues that may arise after the publication of this manuscript.

\section{References}

Ajayan, K.V., M. Selvaraju and K. Thirugnanamurthy, 2011. Growth and heavy metal accumulation potential of microalgae grown in sewage waste water and petrochemical effluents. Pak. J. Biol. Sci., 14: 805-811. PMID: 22545355

Archibald, R.E.M., 1972. Diversity in some South African diatom associations and its relation to water quality. J. Water Res., 6: 1229-1238.

DOI: $10.1016 / 0043-1354(72) 90023-1$

Atici, T., O. Obali, A. Altindag, S. Ahiska and D. Aydin, 2010. The accumulation of heavy metals $(\mathrm{Cd}, \mathrm{Pb}, \mathrm{Hg}$, $\mathrm{Cr}$ ) and their state in phytoplanktonic algae and zooplanktonic organisms in Beysehir Lake and Mogan Lake, Turkey. African J. Biotechnol., 9: 475-487.

Azizi, S.N., A.H. Colagu and S.M. Hafeziyan, 2012. Removal of $\mathrm{Cd}(\mathrm{II})$ from aquatic system using Oscillatoria sp. biosorbent. Scientific World J., 2012: 347053-347059. DOI: 10.1100/2012/347053

Baresova, M., L. Pivokonska and M. Pivokonsky, 2009. How algal organic matter differs in species and growth phase of phytoplankton. J. Int. Water Assoc., 6: 1-2.

Berman, T. and S. Chava, 1999. Algal growth on organic compounds as nitrogen sources. J. Plankton Res., 21: 1423-1437. DOI: 10.1093/plankt/21.8.1423 
Bursali, E.A., L. Cavas, Y. Seki, S.S. Bozkurt and M. Yurdakoc, 2009. Sorption of boron by invasive marine seaweed: Caulerpa racemosa var. cylindracea. Chem. Eng. J., 150: 385-390.

DOI: 10.1016/j.cej.2009.01.016

Cañizares-Villanueva, R.O., S. Gonzalez-Moreno and A.R. Domínguez-Bocanegra, 2001. Growth, nutrient assimilation and cadmium removal by suspended and immobilized Scenedesmus acutus cultures: Influence of immobilization matrix. Proceedings of the 4th Asia-Pacific Conference on Algae and their Biotechnological Potential, Jul. 3-6, Springer Netherlands, pp: 147-161.

DOI: 10.1007/978-94-015-9835-4_11

Chekroun, K.B. and M. Baghour, 2013. The role of algae in phytoremediation of heavy metals: A review. J. Mater Environ. Sci., 4: 873-880.

Davis, T.A., B. Volesky and R.H.S.F. Vieira, 2000. Sargassum seaweed as biosorbent for heavy metals. J. Water Res., 34: 4270-4278.

DOI: 10.1016/S0043-1354(00)00177-9

De la Noüe, J., G. Laliberté and D. Proulx, 1992. Algae and waste water. J. Applied Phycol., 4: 247-254. DOI: $10.1007 / \mathrm{BF} 02161210$

Diwedi, S., 2010. Pollution induced structural and physico-chemical changes in algal community: A case study of river Pandu of North India. J. World Acad. Sci. Eng. Technol., 71: 735-739.

Dwivedi, S., 2012. Bioremediation of heavy metals by algae: Current and future perspective. J. Adv. Lab. Res. Biol., 3: 195-199.

Figueira, M.M., B. Volesky and V.S.T. Ciminelli, 1997. Assessment of interference in biosorption of a heavy metal. J. Biotechnol. Bioeng., 54: 344-350.

Filip, D.S., V.T. Peters, E.D. Adams and J. Middlebrooks, 1979. Residual heavy metal removal by an algae-intermittent sand filtration system. J. Water Res., 13: 305-313. DOI: 10.1016/0043-1354(79)90211-2

Fourest, E. and B. Volesky, 1997. Alginate properties and heavy metal biosorption by marine algae. J. Applied Biochem. Biotechnol., 67: 215-226. DOI: $10.1007 / \mathrm{BF} 02788799$

Fukami, M., H. Ohbayashi, E. Yoshimura, S. Yamazaki and S. Toda, 1988. Effects of zinc on metal metabolism of the zinc tolerant chlorotic mutant of Euglena gracilis Z. J. Agric. Biol. Chem., 52: 2343-2344. DOI: $10.1080 / 00021369.1988 .10869034$

Goswami, D.C., 1998. Ecological Imbalance Afflicts North East India. The Assam Tribune.

Holan, Z.R. and B. Volesky, 1994. Biosorption of lead and nickel by biomass of marine algae. J. Biotechnol. Bioeng., 43: 1001-1009.

DOI: $10.1002 /$ bit.260431102
Horan, N.J., 1989. Biological Wastewater Treatment Systems: Theory and Operation. 1st Edn., John Wiley and Sons, New York, ISBN-10: 0471924253, pp: 320.

Howells, G., 1994. Water Qual Freshwater Fish. 1st Edn., CRC Press, ISBN-10: 2881249221, pp: 222.

Irgolic, K.J., E.A. Woolson, R.A. Stockton, R.D. Newman and N.R. Bottino et al., 1977. Characterization of arsenic compounds formed by Daphnia magna and Tetraselmis chuii from inorganic arsenate. J. Environ. Health Perspectives, 19: 61-61. PMID: 908314

Jaishree and T.I. Khan, 2014. Monitoring of heavy metal in textile waste water of sanganer, Jaipur (Rajasthan). Int. J. Scientific Res. Public., 4: 1-4.

Jothinayagi, N. and C. Anbazhagan, 2009. Heavy metal monitoring of Rameswaram coast by some Sargassum species. Am. Eurasian J. Scientific Res., 4: 73-80.

Jumbe, A.S. and N. Nandini, 2009. Impact assessment of heavy metals pollution of Vartur Lake, Bangalore. J. Applied Nat. Sci., 1: 53-61.

Kraan, S., 2012. Algal polysaccharides, novel applications and outlook. INTECH Open Access Publisher.

Kumar, J.I. and Oommen, C. 2012. Removal of heavy metals by biosorption using freshwater alga Spirogyra hyalina. J. Environ. Biol., 33: 27-31. PMID: 23033639

Kuyucak, N. and B. Volesky, 1988. Biosorbents for recovery of metals from industrial solutions. J. Biotechnol. Lett., 10: 137-142. DOI: $10.1007 / \mathrm{BF} 01024641$

Kuyucak, N. and B. Volesky, 1989. Accumulation of cobalt by marine alga. J. Biotechnol. Bioeng., 33: 809-814. DOI: $10.1002 /$ bit.260330703

Lim, S.L., W.L. Chu and S.M. Phang, 2010. Use of Chlorella vulgaris for bioremediation of textile wastewater. J. Bioresource Technol., 101: 7314-7322. DOI: 10.1016/j.biortech.2010.04.092

Løvdal, T., C. Eichner, H.P. Grossart, V. Carbonnel and L. Chou et al., 2007. Competition for inorganic and organic forms of nitrogen and phosphorous between phytoplankton and bacteria during an Emiliania huxleyi spring bloom (PeECE II). J. Biogeosci. Discuss., 4: 3343-3375.

Mane, P.C. and A.B. Bhosle, 2012. Bioremoval of some metals by living algae Spirogyra sp. and Spirullina sp. from aqueous solution. Int. J. Environ. Res., 6: 571-576.

Matsunaga, T., H. Takeyama, T. Nakao and A. Yamazawa, 1999. Screening of marine microalgae for bioremediation of cadmium-polluted seawater. J. Biotechnol., 70: 33-38. DOI: 10.1016/S0168-1656(99)00055-3

McClanahan, T.R., M. Carreiro-Silva and M. DiLorenzo, 2007. Effect of nitrogen, phosphorous and their interaction on coral reef algal succession in Glover's Reef, Belize. J. Marine Poll. Bull., 54: 1947-1957. DOI: 10.1016/j.marpolbul.2007.09.023 
Mitra, N., Z. Rezvan, M.S. Ahmad and M.G.M. Hosein, 2012. Studies of water arsenic and boron pollutants and algae phytoremediation in three springs, Iran. Int. J. Ecosyst., 2: 32-37.

DOI: $10.5923 /$ j.ije.20120203.01

Mouchet, P., 1986. Algae reactions to mineral and organic micropollutants, ecological consequences and possibilities for industrial-scale application: A review. J. Water Res., 20: 399-412. DOI: $10.1016 / 0043-1354(86) 90186-7$

Palmer, C.M., 1969. A composite rating of algae tolerating organic pollution. J. Phycol., 5: 78-82. DOI: $10.1111 /$ j.1529-8817.1969.tb02581.x

Pokharna, S. and R. Shrivastava, 2013. Photocatalytic treatment of textile industry effluent using titanium oxide. Int. J. Curr. Res. Rev., 2: 9-17.

Rawatani, K. A. and Singh, C.P. 2011. Assessment and characterization of various physico chemical parameters of soil of amanishah nala and its surrounding areas of Jaipur city (Rajasthan, India). J. EM Int., 30: 67-71.

Rehman, A., 2003. Role in bioremediation of heavy metals. Pak. J. Zool., 35: 337-341.

Saikia, M.K. and M.P. Lohar, 2012. Structural and physico-chemical correlation of algal community of a water body affected by pulp and paper mill effluents. Global J. Sci. Frontier Res., 12: 1-13.

Sen, B., F. Sonmez, M.A.T. Kocer, M.T. Alp and O. Canpolat, 2013. Relationship of algae to water pollution and waste water treatment. INTECH Open Access Publisher.

Sethi, S., M.M.M. Shubhum, N. Sharma and S. Gupta, 2012. Biodecolorization of azo dye by microbial isolates from textile effluent and sludge. Univ. J. Environ. Res. Technol., 2: 1-9.

Shanab, S., A. Essa, E. Shalaby, 2012. Bioremoval capacity of three heavy metals by some microalgae species (Egyptian Isolates). J. Plant Signal Behav., 7: 392-399. DOI: 10.4161/psb.19173
Singh, V. and C.S. Chandel, 2006. Analytical study of heavy metals of industrial effluents at Jaipur, Rajasthan (India). J. Environ. Sci. Eng., 48: 103-108.

Subhadra, B., 2011. Algal biorefinery-based industry: An approach to address fuel and food insecurity for a carbon-smart world. J. Sci. Food Agric., 91: 2-13. DOI: $10.1002 /$ jsfa.4207

Tebbutt, T.H.Y., 1997. Principles of Water Quality Control. 5th Ed., Butterworth-Heinemann, ISBN-10: 0080539688, pp: 288.

Travieso, L., R.O. Canizares, R. Borja, F. Bentez and A.R. Dominguez et al., 1999. Heavy metal removal by Microalgae. J. Bull. Environ. Contaminat. Toxicol., 62: 144-151. DOI: $10.1007 / \mathrm{s} 001289900853$

Volland, S., D. Schaumlöffel, D. Dobritzsch, G.J. Krauss and U. Lütz-Meindl, 2013. Identification of phytochelatins in the cadmium-stressed conjugating green alga Micrasterias denticulata. J. Chemosphere, 91: 448-454. DOI: $10.1016 /$ j.chemosphere.2012.11.064

Vymazal, J. 1990. Uptake of lead, chromium, cadmium and cobalt by Cladophora glomerata. J. Bull. Environ. Contaminat. Toxicol., 44: 468-472. DOI: $10.1007 / \mathrm{BF} 01701231$

Wang, T.C., G. Ramesh, J.C. Weissman, R. Varadarajan and J.R. Benemann, 1995. Bioremoval of toxic elements with aquatic plants and algae. Battelle Press, Columbus, OH, ISBN-10: 1-57477-011-X, pp: 65.

Yoshida, N., R. Ikeda and T. Okuno, 2006. Identification and characterization of heavy metal-resistant unicellular alga isolated from soil and its potential for phytoremediation. J. Bioresource Technol., 97: 1843-1849. DOI: 10.1016/j.biortech.2005.08.021 